\title{
Listening to Teachers
}

\author{
Eugenie C. Scott
}

Published online: 7 April 2010

(C) The Author(s) 2010. This article is published with open access at Springerlink.com

\begin{abstract}
The author reflects on how much she has learned about teaching from K-12 teachers, and about the difficulties teachers encounter when they teach about evolution. Misconceptions and preconceptions, especially those concerning the compatibility or incompatibility of evolution with religion, are difficult to overcome, but teachers have devised many ingenious approaches to "defuse the religion issue." The easy way out for many teachers is to omit evolution, or compromise its teaching by either including creationism or denigrating evolution, but the many teachers who teach with integrity are inspiring to us all.
\end{abstract}

\section{Keywords Evolution education · Creationism - Evolution}

One of these days I want to write a book. Not a book about creationism and evolution-been there, done that (Scott 2009). Nor a book about intelligent design - Glenn Branch and I edited a book on that topic (Scott and Branch 2006). No, this book is going to be about teachers and some of the things I have learned from them.

I certainly learned the difference between being a good teacher and being a good lecturer. Although I was considered a good teacher when I was a university professor in the 1970s and 1980s, I now cringe at some of the things that were considered perfectly good pedagogy back then (don't ask) that I would never do now. Watching and listening to some master teachers has taught me how difficult it is to really teach someone something so that it sticks beyond the final examination.

I didn't know anything about the five E's-engage, explore, explain, elaborate, and evaluate-for example. I

E. C. Scott $(\bowtie)$

National Center for Science Education,

Oakland, CA, USA

e-mail: scott@ncse.org thought it was sufficient to, Monty Python-like, just tip back the students' calvaria and pour in the information. Wrong. When it comes to evolution, the most important $\mathrm{E}$ is engage, and the most important part of engagement is to figure out what the learner already has in his or her brain when encountering the concept of evolution. With less familiar concepts such as cell division, or mass, or energy, a learner is not likely to have a lot of preconceptions. But, in the case of evolution, there already is plenty of content resident in that brain, and the new information poured in doesn't just replace the old without a struggle.

And oh my, what students think about evolution before they get to the classroom in itself could fill up that book. A high school student told me that, according to his Sunday school teacher, evolution explained the origin of humans as follows: "two gorillas mated and out came human beings." Another claimed that evolution was when a lizard laid an egg and out flew a bird. More than once I've heard that evolution couldn't be true because no one has ever seen a monkey turn into a human. Another solemnly proclaimed that scientists construct fossils for other scientists to bury, and then other scientists dig them up and reconstruct them (which of course makes one wonder why they go to remote and uncomfortable places like the Gobi, Afar, Wyoming, and northern Greenland to hide them rather than Napa Valley, Hawai'i, or Tuscany). Then there was the student who asked her teacher whether Adam and Eve spoke English....

Of course the elephant in the room is religious opposition to teaching evolution. Sometimes it's standing there quietly, with everyone politely ignoring it, and sometimes it's trumpeting loudly, stomping its feet and throwing the furniture around. Something else I have learned from teachers - and passed on to others - is ways of, as we put it at NCSE, "defusing the religion issue." 
Key to avoiding this particular educational minefield is to confront the perspective held by such a large percentage of our fellow citizens that it is necessary to choose between evolution and faith. At the heart of the creationism and evolution controversy in the United States is the idea that faith (in particular Christian faith) is incompatible with acceptance of evolution; people are not motivated to go to school board meetings and protest the curriculum unless the stakes are high, and the prospect of eternal damnation qualifies. But of course the idea that faith and evolution are irreconcilable is simply empirically false. True enough, there are versions of Christianity that are incompatible with acceptance of evolution, but there are even more versions of Christianity that accept it. Although it is not the job of the teacher to try to change the students' religious views (and it would be inappropriate to do so), broadening their horizons by descriptively informing them of some of the views between the two extremes has a striking effect in reducing some students' apprehension about learning evolution.

There are, of course, many ways of helping students see the creationism and evolution continuum, which I have discussed in a number of articles that I have written (especially Scott [2004]). Some teachers use an exercise that walks students through some Christian perspectives on evolution (some accepting and some rejecting), others have had students interview religious professionals and share the results in class (illustrating, in all but the most homogeneous communities, the diversity of opinion among people of faith regarding evolution and creationism), and there are other approaches as well.

It is also the case that many teachers never have any problems teaching evolution and happily teach it as matterof-factly as they teach any other subject in science: would that it were more commonly so! And I've learned plenty from them about how to teach evolution more effectively.

But in addition to teaching me about teaching, listening to teachers has also given me some great stories - some of which have made me laugh, some of which have made me cry, and some of which have made me want to throw something (or someone?) against the wall.

Many of these stories involve opposition to the teaching of evolution-from both expected (students, parents) and unexpected (colleagues, administrators) quarters. Perhaps the latter is the most discouraging: one always hopes that support for teaching evolution will come from fellow professionals, but disappointment is often close at hand. An Illinois teacher told me of his friend in a neighboring district who casually mentioned to other teachers that he was going to begin a unit on evolution the next day "and the look he got was like he threw a rattlesnake on the table." A similar reaction was engendered by a young Kentucky teacher in Owensboro years ago. Her colleagues were aghast- "we don't teach that here!"- but she was a young and enthusiastic teacher, trained in a good teacher education program, and determined to give her students a solid education. So she just (inaccurately, unfortunately) substituted the word "development" for the word "evolution" throughout the semester. She talked about the "development" of single-celled organisms into multicelled organisms and the "development" of fish into tetrapods, and so on, and of course the students were enthralled. Only at the end of the semester did she slip and mention the e-word. A hand shot up.

"Teacher-you can't say that here," said the student.

"Tim, do you remember when we talked about the development of chordates from echinoderm larvae and the development of fish into tetrapods and so on?"

"Yeah."

"Well, that's evolution."

"No, it isn't. Evolution means you can't believe in God."

To most people, evolution means that man evolved from monkeys and you can't believe in God. Those two ideas are related. To many, evolution means that humans were not specially created in their present form, which means (to those of a particular view of Christianity) Genesis is not true, hence there is no God. It's downhill from there. Others don't like the idea that we descended from monkeys because monkeys are icky. They smell and they throw poop at you at the zoo. Of course, apes and monkeys are highly intelligent, use or even make tools, have high levels of communication abilities, can build political alliances, show empathy to strangers, nurture kin, and otherwise exhibit extraordinary levels of social and intellectual behaviors, and in many ways are worthy of admiration. Alas, most of the students who consider primates icky don't know any of this and are unlikely to learn it without studying evolution. That's too bad, since in studying evolution they would learn that, in fact, we didn't evolve from monkeys, though we share common ancestors with them-indeed, you share a common ancestry with Eutheria and Utahraptor, and with yew and eucalyptus, and with euglena and eubacteria besides. The big idea of evolution is the common ancestry of all living things - but students not taught evolution are likely to understand only the "street" definition of "man evolved from monkeys."

What evolution means to people is worth a book in itself, actually. One teacher related a story of a parent who said he "didn't want her teaching that evolution stuff," so she offered, "how about if I teach natural selection?" $\mathrm{He}$ thought a minute and said, "Well, I guess that's okay." Recalling the story, the teacher wryly remarked, "As long as I didn't tell his kid that he came from a monkey, I could teach him anything."

As a result of this pervasive antievolutionism, there are plenty of outside pressures on teachers not to teach evolution. I hear from teachers who are told by administrators 
to "just skip evolution this year" because a school board election is coming up and "we don't want any trouble." Hidden deep in the contract of administrators, there must be a "don't make waves" clause the rest of us don't hear about. On the other hand, there are excellent role models like high school science department chair Ken Hubert of Faribault, Minnesota, who knew something wasn't right with the new biology teacher, Rodney LeVake. Faribault High School's biology curriculum requires evolution to be taught, and LeVake refused to comply. Worse, he told students that evolution was questionable science, thus undermining the teaching of colleagues, and even gave students credit for reading creationist articles. After clarifying LeVake's position, Hubert called in the principal and superintendent. It was clear that the education of students would suffer if LeVake remained a biology teacher, so he was reassigned to teach a different science course.

This unfortunately resulted in what every administrator tries to avoid-a lawsuit. Rodney LeVake sued the Faribault district, accusing it of violating his religious freedom by reassigning him from teaching biology to teaching general science. The court disagreed, ruling that the district had a right to determine the curriculum and that LeVake had to teach it. His right to free exercise of his religion was not violated by having to teach the same curriculum as the other biology teachers (see Moore [2004] for Hubert's story).

The Faribault district's decision to transfer a teacher out of a biology class for not teaching evolution might not have happened everywhere. Too many administrators find it much easier to look the other way when a teacher is skipping evolution or, worse, teaching creationism. It's so much easier just not to rock the boat, and administrators hate the feeling of rocking boats. Yet more timid administrators in other districts should realize that the Faribault administrators' actions protected rather than jeopardized the district-because had LeVake ever taught creationism and had the district been sued as a result, it surely would have lost. Every creationism and evolution case has been won by the evolution side. Every single one-after the Scopes trial of 1925, that is. A district is in a much better position to be a defendant where the case law is firmly on its side, as it was in LeVake v. ISD 656, than trying to defend itself against the charge of letting creationism be taught. Hubert and his colleagues did the right thing for the district, and more importantly, for the students in the district.

Another example of teachers doing the right thing, of course, took place in Dover, Pennsylvania. Teachers initially were intimidated by school board members who aggressively promoted creationism and antievolutionism in various ways, for example by opposing a mainstream biology textbook, accusing it of being "laced with Darwinism." After months of efforts involving compromises that largely were unreciprocated, the Dover teachers eventually were forced to draw their own line in the sand. They became heroes to teachers everywhere when they unanimously refused to read a pedagogically unsound, board-imposed evolution disclaimer to students, which forced administrators to come to each classroom to read the offensive paragraph themselves. Some of the Dover teachers even became plaintiffs in a suit against the district and prevailed in Kitzmiller v. Dover, the case that declared intelligent design illegal to teach in public schools. (For the whole story of Kitzmiller, see Humes [2007] and Lebo [2008].)

In this future book of mine, I will write about not only the bravery but also the amiability of teachers. Teachers are among the more genial of people. This is a helping profession: one goes into teaching because one wants to make a difference and because one likes children. You like a good fight? Become a lawyer. Teachers, in my experience, tend to be non-combative and try to avoid conflict with parents. When a parent complains about little Johnny or Susie having to learn evolution, the natural tendency of a teacher is to avoid conflict. For some teachers, unfortunately, that means leaving out evolution. For others, that means trying to teach it on the sly. Some students at a Governor's School in North Carolina reported that their teachers told them that "evolution was just a theory, so don't go home and tell your parents what we're doing here." Responsible teachers, on the other hand, have developed ways to finesse the situation so that ruffled feathers are smoothed but good science is taught.

The most straightforward (and easiest) finesse is to kick the problem upstairs: hide behind the curriculum or the state standards. I learned this from a high school teacher in California, where the middle school and high school state science education standards are very strong in evolution. Back in the early 1990s, this teacher found himself facing three parents one afternoon. They were there because they were unhappy about his plans to begin teaching evolution the next week. Not wanting to argue with them, he calmly showed them the California Science Framework, which has a very strong presentation of evolution for the high school curriculum. "It's my job to teach them the Framework," he told them. The three parents sat there, in some frustration. Finally, one of them looked up. "Well," he said, "You don't have to teach it like you mean it." Knowing this teacher, he taught it, and he meant it.

So this book I hope to write will contain lots of stories of the tales of teachers. Some won't require comment, like the story of the teacher who asked a student to provide a 
reference for his claim in a term paper that Darwin recanted evolution on his deathbed and was threatened with a lawsuit by the student's father. (Well, here's a comment: Darwin's deathbed recantation is, of course, a myth [see Moore 1994].)

And there's the story of the teacher in the laboratory class on human evolution who asked the students to determine the sex of the mounted skeleton-a task requiring examination of diagnostic parts of the skull and pelvis - and one of the students started counting the ribs. (The student was thinking of Genesis 2:20-22- "And the LORD God caused a deep sleep to fall upon Adam and he slept: and he took one of his ribs, and closed up the flesh instead thereof; And the rib, which the LORD God had taken from man, made he a woman, and brought her unto the man"- and inferring that men must thus have one fewer rib than women.)

I cheated there. That last teacher was me. But I'm not the only one to have had such an experience (see, for example, Root-Bernstein [1995]). And in general, university professors also have good stories to tell about the challenges of teaching evolution to tell, too, because they inherit their students from the $\mathrm{K}-12$ teachers.
When it comes to evolution education, we're all in this together, and we'd better listen to those teachers.

Open Access This article is distributed under the terms of the Creative Commons Attribution Noncommercial License which permits any noncommercial use, distribution, and reproduction in any medium, provided the original author(s) and source are credited.

\section{References}

Humes E. Monkey girl: evolution, education, religion, and the battle for America's soul. New York: Ecco; 2007.

Lebo L. The devil in Dover: an insider's story of Dogma v. Darwin in small-town America. New York: New Press; 2008.

Moore JR. The Darwin legend. Grand Rapids: Baker Book House; 1994.

Moore R. Standing up for our profession: a talk with Ken Hubert. The American Biology Teacher. 2004;66(5):325-7.

Root-Bernstein RS. Darwin's rib. Discover. 1995;16(9):38-41.

Scott EC. The creation/evolution continuum. Skeptic. 2004;10 (4):50-4.

Scott EC. Evolution versus creationism: an introduction. 2nd ed. Berkeley: University of California Press; 2009.

Scott EC, Branch G, editors. Not in our classrooms: why intelligent design is wrong for our schools. Boston: Beacon; 2006. 